\title{
Combining Ability and Heterosis in Diallel Analysis of Maize (Zea mays L.) Lines
}

\author{
Francis Chukwuma Onejeme ${ }^{1 *}$, Emmanuel Ogbonna Okporie $^{2}$, Chinedu Emmanuel Eze $^{3}$ \\ ${ }^{1}$ Department of Crop Science and Horticulture, Nnamdi Azikiwe University, \\ Awka, P. M. B. 5025, Awka, Anambra State, Nigeria. \\ ${ }^{2}$ Department of Crop Production and Landscape Management, Ebonyi State University, \\ Abakaliki, P. M. B. 053, Abakaliki, Ebonyi State, Nigeria. \\ ${ }^{3}$ Department of Agronomy, Michael Okpara University of Agriculture, \\ Umudike, P. M. B. 7267, Umuahia, Abia State, Nigeria.
}

* Corresponding author email: francis.onejeme@gmail.com

Received: 21 March 2020 / Revised: 15 June 2020 / Accepted: 04 July 2020 / Published: 07 July 2020

\begin{abstract}
A sound breeding program for maize improvement is very important to meet the demands of the growing population. Therefore, combining ability and heterosis were studied in a $4 \mathrm{x} 4$ full diallel cross in maize for growth attributes, yield and its contributing traits. Randomized Complete Block Design (RCBD) with four replicates was used to study the general combining ability of parents, specific combining ability of F1s (including reciprocals) and heterosis of the F1s over commercial check variety on selected agronomic characters. Genotype was highly significant for all the traits studied. The combining abilities (GCA and SCA) and reciprocal mean squares were highly significant for most studied characters. The ratio of GCA/SCA was not less than unity for studied traits excepted for days to anthesis and ear height. The results indicated that the additive genetic effects were more important and played major role in studied traits. Thus, results revealed GCA effects for the parental lines (PL). Where 'PL2' was excellent combiner for number of tassels and cob circumference and 'PL3' was good combiner for days to silking and grain yield (t.h-1). While 'PL4' for short height. Majority of the F1s from the GCA effects showed high SCA effects. This F1 (PL2 x PL3) performed best amongst. However, several reciprocals were not desirable. Heterosis estimation was carried out using a commercial check, Oba super II. When commercial check was used, the percent heterosis especially on grain yield varied from -8.89 to $22.62 \%$. Among the twelve F1s, nine of the crosses exhibited significant positive heterosis for grain yield $\left(\mathrm{t}^{-} \mathrm{h}^{-1}\right)$. Those $\mathrm{F} 1 \mathrm{~s}$ that showed significant positive and/or negative desirable traits for SCA effects and significant positive heterosis could be used for varietal development in maize breeding. And conservation of those parents that exhibited high GCA effects be considered as well.
\end{abstract}

Keywords: Maize; general combining ability; specific combining ability; reciprocal effects; heterosis.

\section{Introduction}

Maize (Zea mays L.) is one of the major cereal crops belonging to the order- Oales, familyPoaceae, and sub family- Panicoideae. It is grown virtually all over the world especially in the humid tropics and Sub-Saharan Africa. Maize is a versatile crop with third ranking position after wheat and rice in world production [1]. Maize crop forms fundament source of livelihood (food, income, self-reliance, etc.) for millions of people in many nations of the world. It is produced widely in Nigeria, where it is consumed cooked, roasted, fried, pounded, baked or fermented [2]. In advanced countries, not limited by the list such as United States, China, and Europe, maize is a significant source of several industrial products like corn flour, corn sugar, starch, corn oil, syrup, alcohol and brewer's grit [3]. 
Combining ability studies offer information on the genetic mechanisms governing the inheritance of traits and assist the breeders to choose suitable lines (parents) for further crop improvement. In biometrical genetics, the two types of combining abilities are general combining ability (GCA) and specific combining ability (SCA). General combining ability defined as the average performance of the genotype in a series of hybrid combinations and is a measure of additive gene effect. While specific combining ability refers to the performance of the genotype in a specific cross in relation to the formal and is a measure of non-additive gene effect [4]. Diallel mating models designed by Griffing [5] and Gardner and Eberhart [6], are the standard models used in combining ability analyses. Combining ability in maize grain yield has been studied exclusively and the findings have been extensively used in maize breeding programs [7] - [10]. Combining ability analyses as adopted in maize breeding programs are for the estimate of GCA and SCA information from maize populations for genetic diversity evaluation, heterotic pattern classification and estimation, inbred line selection, and hybrid development [7], [9], [10]. Rojas and Sprague [11], reported that the value of an inbred line in the commercial hybrid maize depends on two factors. The characteristic of the line itself with regard to pollen shedding, yielding ability, disease resistance, etc. and the behavior of the line in hybrid combinations. Over the decades, the combining ability concept has become increasingly imperative not only in maize breeding programs but as well in other crops.

Heterosis refers to the phenomenon that progeny of diverse varieties of a species or crosses between species exhibit greater performance over the parents; and models like dominance, overdominance and pseudo-overdominance can be used to explain it. Heterosis and combining ability are considered as the prerequisites for developing an economically viable species (esp. maize variety). The phenomenon of heterosis has been exploited widely in plant breeding programs, leading to significant yield increase. It is adopted describing this phenomenon when the parents evolve from different populations of the same species, however, hybrid vigour explains the concept when the parents are from different species [12]. Remarkably, the heterosis of mules - "the ability to perform additional work with fewer resources," was widely utilized in agriculture preceding mechanization [13]. Heterosis and inbreeding depression in maize was originally documented by C. G. Hopkins [14] and George H. Shull $[15,16]$. Thus, the adoption of hybrid maize over open-pollinated varieties seem to be transpired fast due to increase in yields, uniformity in crop maturity and harvesting as with mechanization, and improved durability under extreme abiotic stress [14], [15, 16]. Moreover, the pervasive utilization of heterosis now profiles breeding programs for numerous agriculturally exciting species containing maize and rice. Therefore, interest in developing approaches to characterize the molecular basis of heterosis, and to predict hybrid performance to upsurge the efficiency of hybrid breeding programs are sought. Of which researchers have attempted to utilize RNA expression levels of genes [17], genomic sequence [18], sRNAs [19, 20], metabolomic [18, 21], proteomic [22] and data to dissect heterosis [23]. Hence, relationships have been recognized exhausting each of these data types, and no data type is wholly capable to predict hybrid performance individually [24]. Though, attempts to predict hybrid performance are complex by the fact that heterosis intensities vary for different characters within the same hybrid [25]. In this regard, plant breeders have observed that hybrid genotypes are more stress tolerant than their inbred parents, this conclusion was supported by few published reports, mainly in environments with moderate rather than extreme levels of abiotic stress. For instance, Arabidopsis, stress response gene expression networks have been revealed contributing to heterosis and prediction of hybrid performance [26, 27]. As an outcrossing plant, maize generally displayed stronger heterosis by showing range $(50 \%-100 \%)$ in yields over openpollinated varieties [28]. Consequently, hybrid breeding is very influential in maize and virtually all commercial maize cultivars are hybrid lines nowadays. In addition, applications of heterosis in grain crops, hybrid breeding as well is one of the great adoptions in several plants including 
rapeseed, sunflower and tomato [29, 30, 31]. Numerous studies via the RIL populations and the backcross population (RILBC1, derived from mating RIL with PA64S) had been made and identified several major quantitative trait loci (QTLs) fundament yield heterosis [32]. In maize, parallel with the experimental design for the elite rice hybrid "Shanyou63", the "immortalized F2" population gotten from the elite maize hybrid Yuyu22 was developed [33]. This was on a highdensity bin map from a single nucleotide polymorphism (SNP) genotyping chip, the genetic study in maize established that the yield heterosis in this hybrid maize Yuyu22 relied on the aggregate effects of dominance, overdominance and epistasis. The dominance effect was the most significant contributor to heterosis [34]. Although classical genetic models have clarified to some extent the genetic basis of heterosis, but still not sufficient to predict heterosis. Epigenetic factors, containing DNA methylation, histone modification and small RNAs, play vital roles in plant development and adaptation [35]. Likewise, there is growing evidence that epigenetics is one of the gap fillers in thoughtful of heterosis regulation [36, 37].

Maize production estimated approximately 100 million hectares in 125 developing countries and was considered the most widely grown crops in 75 of those countries [38]. According to Rosegrant et al. [39], maize demand between 2009 and 2050 in the developing world will double, and by 2025 , maize production is expected to be maximum globally, especially in those developing countries. Also, the production may not meet the demands without a strong technological and policy interventions. Therefore, a sound breeding programme should be used to produce high yielding varieties like inbred lines. Inbred lines are prerequisite for hybrid development, especially in maize breeding. Combining ability analysis to this regard is of special importance in cross-pollinated crops (esp. maize), as it aids in identifying potential parents that produce hybrids and synthetics [40].

Thus, the present study used $4 \times 4$ full diallel cross to evaluate the general combining ability of parents, highly performed crosses on the basis of specific combining ability (with reciprocals) and heterosis of crosses (F1s and reciprocals) over commercial check variety on growth attributes, yield and its contributing traits.

\section{Materials and methods}

These four parental lines were used: Obatamkpa, Oba 98, Oba super I and Ikom white (a local line). The maize lines were differed considerably in expression of several agronomy characters. The experiment was conducted at the Teaching and Research Farm of Crop Science and Horticulture, Faculty of Agriculture, Nnamdi Azikiwe University, Awka, Anambra State of Nigeria, during the 2018 (when crosses were made) and 2019 (evaluation was conducted) cropping seasons. The site is located at latitude 6.2501070 North and longitude $7.118967^{\circ}$ East at an altitude of $183 \mathrm{~m}$ above sea level. Its annual mean rainfall is about $1,798.52 \mathrm{~mm}$, with average mean relative humidity of $82 \%$ and an average temperature of about $26^{\circ} \mathrm{C}$. The soil textural class is sandy loam [41].

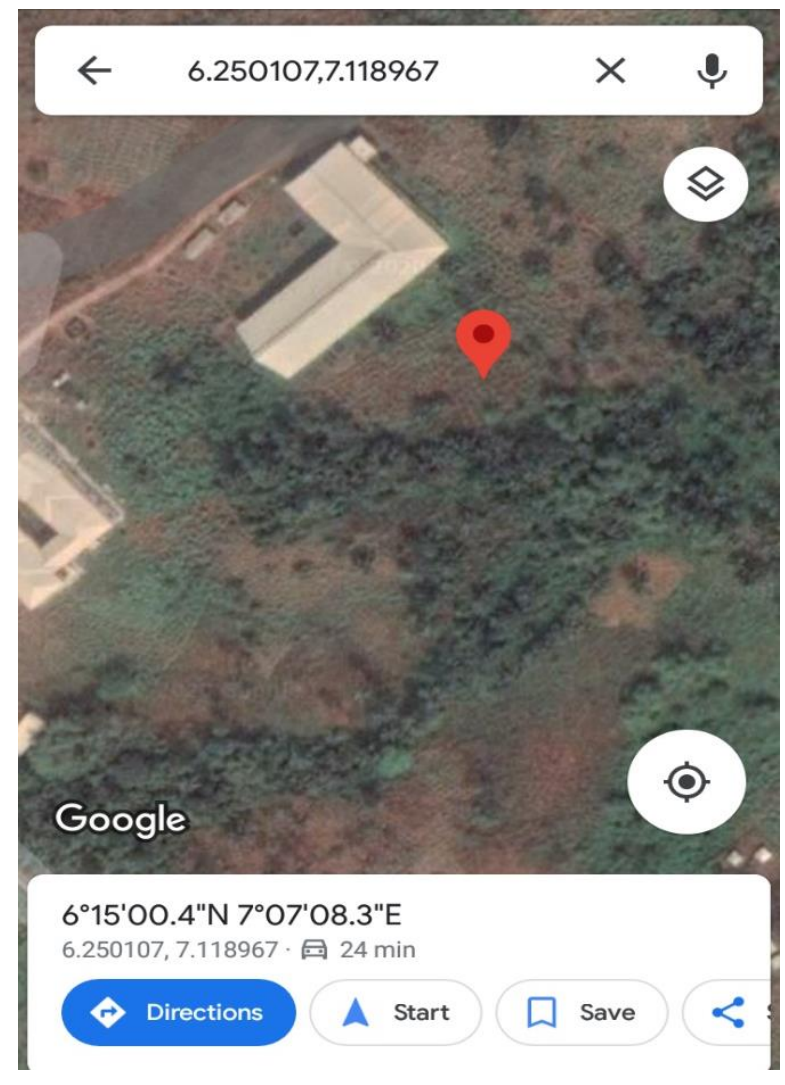

Figure 1: Satellite view of the experimental site location.

(https://google.com/map/place/nau/@6.250107,7.118967). 
The four parental lines were crossed in a 4 x 4 full diallel cross to give twelve (12) crosses, including reciprocal crosses. The parents and their twelve (12) crosses and a commercial check hybrid (Oba super II) were evaluated in a randomized complete block design (RCBD) with four replications. In this study, the designations of maize lines used in the crosses were (Parental line - PL): Obatamkpa as PL1, Ikom white as PL2, Oba 98 as PL3, and Oba super I as PL4. The crosses (F1s and reciprocals) were designated as PL1 x PL2, PL1 x PL3, PL1 x PL4, PL2 x PL1, PL2 x PL3, PL2 x PL4, PL3 x PL1, PL3 x PL2, PL3 x PL4, PL4 x PL1, PL4 x PL2, and PL4 x PL3.

Kernels were planted at 2-3 grains per hill then thinned one plant per hill after emergence. Each replication contained 17 plotted experimental units and each plot $(3 \mathrm{~m} \times 5 \mathrm{~m})$ consisted of four ridges with spacing of $25 \mathrm{~cm}$ between plants and $75 \mathrm{~cm}$ between ridges. During 2018 and 2019 planting seasons, a compound fertilizer (NPK 20:10:10) was applied at the recommendation rate for maize [42] consists of $60 \mathrm{~kg} \mathrm{~N} \mathrm{~h}^{-1}, 30 \mathrm{~kg} \mathrm{P} \mathrm{h}^{-}$ ${ }^{1}$ and $30 \mathrm{~kg} \mathrm{~K} \mathrm{~h}^{-1}$ at 2 weeks after planting (WAP). Soil test of the experimental site was conducted during each cropping season. Manual weed control was observed for both cropping seasons. In addition, both planting seasons were supplied with an additional $60 \mathrm{~kg} \mathrm{~N} \mathrm{~h}^{-1}$ as top dressing at 7 WAP using urea (46\% N). During 2019 cropping season (evaluation was conducted), observations were taken and recorded from 15-20 randomly selected plants situated at the middle rows of each plot for plant height $(\mathrm{cm})$, ear height $(\mathrm{cm})$, cob circumference $(\mathrm{cm})$, cob length $(\mathrm{cm})$, number of seeds per cob, and number of tassels per plant. Hence, days to anthesis, days to silking, anthesis silking interval (days), days to maturity, 1000-seed weight $(\mathrm{g})$ and grain yield $\left(\mathrm{t} . \mathrm{h}^{-1}\right)$ were recorded on whole plot basis.

Data were analyzed for variance on all the studied characters. The mean performance of studied traits were analyzed using GenStat statistical package $4^{\text {th }}$ Edition [43]. Means were separated using Fisher`s Protected Least Significant Difference at 5\% level of probability. General combining ability (GCA) and specific combining ability (SCA) were estimated following Model I,
Method I of Griffing [5]. The mean squares for GCA and SCA were tested against error variance desired using the mean data of all the single cross hybrids and commercial check variety, which was estimated and tested according to Singh and Singh [44]. Thus, percent heterosis was calculated by formula below:

$$
\text { Standard Heterosis }(\%)=\left[\left(\mathrm{F}_{1}-\mathrm{CV}\right) / \mathrm{CV}\right] \times 100
$$

Where, $F_{1}$ and $C V$ represented the mean performance of hybrid and commercial check variety (CV). The significance test for heterosis was done by using standard error of the value of commercial check variety.

\section{Results and Discussion}

\subsection{Characteristics of the soil used for the study}

The pre-planting analyses of soil properties in both seasons are shown in Table 1. The result indicated that the textural class of the study site is sandy loam. The soil $\mathrm{pH}$ (water and calcium salt) ranged from 6.4-6.8 and 5.5-6.1 in both years respectively, indicating slight acidity. This was supported, rated and reported by Landon [45]. Organic carbon $(2.0 \mathrm{~g} / \mathrm{kg})$ was same in both planting seasons while total nitrogen and available phosphorus in 2019 planting season were higher compared to 2018 planting season $(1.8$ and $1.4 \mathrm{~g} / \mathrm{kg} ; 13.5$ and $9.5 \mathrm{mg} / \mathrm{kg}$ ), respectively. As expected for the critical levels of $1 \mathrm{~g} / \mathrm{kg} \mathrm{N}$ and 10-12 mg/kg P [46], this indicated that the soil was in good shape for some essential soil nutrients in both years. The pre-planting exchangeable cations content of the study site in $2019\left(\mathrm{Na}^{+}\right.$0.17, $\mathrm{K}^{+}$0.08, $\mathrm{Mg}^{2+} 3.2$ and $\mathrm{Ca}^{2+} 4.0$ $\mathrm{cmol} / \mathrm{kg}$ ) were higher when compared with values obtained in $2018\left(\mathrm{Na}^{+} 0.15, \mathrm{~K}^{+} 0.05, \mathrm{Mg}^{2+}\right.$ 2.8 and $\mathrm{Ca}^{2+} 3.6 \mathrm{cmol} / \mathrm{kg}$ ) cropping season. However, using the critical level of $0.2 \mathrm{cmol} / \mathrm{kg}$, exchangeable $\mathrm{K}$ was very low [47]. Exchangeable acid was only available during 2018 pre-planting season $(0.10 \mathrm{cmol} / \mathrm{kg})$. The soil was found to be deficient in some soil nutrients with respect to maize production. The result could be attributed to long term cropping of the land. 
Table 1: Physico-chemical properties of the soil used in the experiments.

\begin{tabular}{lll}
\hline Soil properties & Values in $\mathbf{2 0 1 8}$ & Values in 2019 \\
\hline Sand & $790 \mathrm{~g} / \mathrm{kg}$ & $790 \mathrm{~g} / \mathrm{kg}$ \\
Silt & $100 \mathrm{~g} / \mathrm{kg}$ & $100 \mathrm{~g} / \mathrm{kg}$ \\
Clay & $110 \mathrm{~g} / \mathrm{kg}$ & $110 \mathrm{~g} / \mathrm{kg}$ \\
Soil Textural Class & Sandy loam & Sandy loam \\
$\mathrm{pH}: 1: 2.5\left(\mathrm{H}_{2} \mathrm{O}\right.$ and $\left.\mathrm{CaCl}_{2}\right)$ & 6.4 and 5.5 respectively & 6.8 and 6.1 respectively \\
Organic Carbon & $2.0 \mathrm{~g} / \mathrm{kg}$ & $2.0 \mathrm{~g} / \mathrm{kg}$ \\
Total Nitrogen & $1.4 \mathrm{~g} / \mathrm{kg}$ & $1.8 \mathrm{~g} / \mathrm{kg}$ \\
Avail. Phosphorus & $9.5 \mathrm{mg} / \mathrm{kg}$ & $13.5 \mathrm{mg} / \mathrm{kg}$ \\
Exch. Bases $\left(\mathrm{Na}^{+}, \mathrm{K}^{+}, \mathrm{Mg}^{2+}\right.$ and $\left.\mathrm{Ca}^{2+}\right)$ & $0.15,0.05,2.8$ and $3.6 \mathrm{cmol} / \mathrm{kg}$ respectively & $0.17,0.08,3.2$ and $4.0 \mathrm{cmol} / \mathrm{kg} \mathrm{respectively}$ \\
Exch. Acid & $0.10 \mathrm{cmol} / \mathrm{kg}$ & $* * * *$ \\
\hline
\end{tabular}

Na: Sodium, K: Potassium, Mg: Magnesium, Ca: Calcium.

Table 2: Mean performance of maize genotypes on growth attributes, yield and its contributing characters obtained from $4 \times 4$ full diallel cross.

\begin{tabular}{|c|c|c|c|c|c|c|c|c|c|c|c|c|}
\hline Genotypes & $\begin{array}{c}\text { DA } \\
\text { (days) }\end{array}$ & $\begin{array}{c}\text { DS } \\
\text { (days) }\end{array}$ & $\begin{array}{c}\text { ASI } \\
\text { (days) }\end{array}$ & $\begin{array}{l}\text { PH } \\
(\mathbf{c m})\end{array}$ & $\begin{array}{c}\text { EH } \\
(\mathbf{c m})\end{array}$ & $\begin{array}{c}\text { DM } \\
\text { (days) }\end{array}$ & NT & $\begin{array}{c}\mathrm{CC} \\
(\mathrm{cm})\end{array}$ & $\begin{array}{c}\mathrm{CL} \\
(\mathrm{cm})\end{array}$ & NS & $\begin{array}{c}\text { TSW } \\
\text { (g) }\end{array}$ & $\begin{array}{c}\text { GY } \\
(t / h)\end{array}$ \\
\hline PL1 (Obatamkpa) & 57.50 & 63.00 & 5.50 & 193.40 & 68.90 & 143.25 & 16.50 & 13.43 & 13.38 & 341.80 & 188.10 & 6.00 \\
\hline PL2 (Ikom white) & 57.75 & 63.25 & 5.50 & 190.00 & 69.70 & 143.25 & 25.50 & 15.04 & 15.04 & 362.20 & 211.30 & 5.25 \\
\hline PL3 (Oba 98) & 56.25 & 59.50 & 4.25 & 197.90 & 65.10 & 139.50 & 13.25 & 13.83 & 13.96 & 466.50 & 213.90 & 6.74 \\
\hline PL4 (Oba super I) & 56.25 & 64.25 & 3.25 & 177.90 & 79.30 & 139.50 & 19.75 & 13.73 & 14.10 & 473.50 & 179.50 & 5.54 \\
\hline PL1 x PL2 & 56.50 & 65.25 & 8.75 & 221.80 & 90.40 & 142.00 & 25.00 & 14.04 & 13.58 & 362.50 & 224.80 & 5.94 \\
\hline PL1 x PL3 & 56.75 & 62.25 & 5.50 & 219.10 & 75.40 & 142.25 & 16.25 & 14.04 & 14.46 & 460.00 & 211.80 & 6.80 \\
\hline PL1 x PL4 & 58.00 & 64.75 & 6.75 & 176.10 & 81.60 & 144.75 & 22.75 & 14.04 & 14.92 & 452.00 & 185.80 & 6.24 \\
\hline PL2 x PL1 & 55.50 & 61.00 & 5.50 & 236.60 & 96.80 & 141.00 & 24.00 & 15.40 & 16.69 & 521.80 & 202.80 & 5.07 \\
\hline PL2 x PL3 & 61.00 & 62.00 & 5.75 & 247.90 & 100.00 & 145.75 & 23.25 & 15.95 & 18.54 & 558.80 & 269.10 & 6.83 \\
\hline PL2 x PL4 & 56.50 & 61.75 & 5.25 & 193.30 & 81.40 & 141.75 & 21.50 & 15.15 & 16.88 & 541.50 & 243.90 & 5.07 \\
\hline PL3 x PL1 & 56.25 & 60.00 & 3.75 & 224.70 & 86.20 & 140.00 & 19.00 & 14.57 & 16.46 & 471.00 & 224.80 & 6.62 \\
\hline PL3 x PL2 & 55.00 & 57.50 & 2.50 & 227.30 & 83.00 & 137.50 & 23.00 & 15.98 & 17.73 & 509.20 & 250.00 & 6.66 \\
\hline PL3 x PL4 & 56.00 & 60.50 & 4.50 & 200.50 & 84.70 & 140.50 & 24.00 & 14.73 & 14.54 & 444.80 & 213.60 & 6.04 \\
\hline PL4 x PL1 & 55.75 & 60.75 & 5.00 & 195.20 & 83.20 & 140.75 & 23.00 & 14.46 & 15.44 & 434.00 & 236.70 & 5.71 \\
\hline PL4 x PL2 & 56.00 & 61.50 & 5.50 & 191.40 & 89.20 & 141.50 & 31.75 & 14.44 & 16.04 & 415.20 & 264.50 & 5.60 \\
\hline PL4 x PL3 & 56.00 & 62.25 & 6.25 & 199.90 & 86.70 & 142.25 & 22.00 & 14.17 & 15.29 & 454.30 & 211.70 & 6.58 \\
\hline Oba super II & 56.50 & 62.25 & 5.75 & 231.20 & 86.50 & 142.25 & 22.50 & 14.34 & 16.17 & 511.30 & 203.40 & 5.57 \\
\hline $\mathrm{F}$ - test & $* * *$ & $* *$ & $*$ & $* * *$ & $* * *$ & $* *$ & $* * *$ & $* * *$ & $* * *$ & $* * *$ & $* *$ & $*$ \\
\hline Mean & 56.68 & 61.87 & 5.25 & 207.30 & 82.80 & 141.63 & 21.94 & 14.61 & 15.48 & 457.70 & 219.70 & 6.02 \\
\hline SE & 0.700 & 1.267 & 0.974 & 7.540 & 5.330 & 1.237 & 1.373 & 0.344 & 0.822 & 32.650 & 15.740 & 0.434 \\
\hline $\mathrm{CV}(\%)$ & 2.20 & 1.10 & 29.70 & 3.00 & 4.30 & 0.50 & 3.10 & 1.00 & 4.50 & 5.50 & 7.40 & 8.80 \\
\hline $\operatorname{LSD}_{(0.05)}$ & 1.990 & 3.602 & 2.769 & 21.430 & 15.150 & 3.518 & 3.905 & 0.978 & 2.338 & 92.850 & 44.750 & 1.233 \\
\hline
\end{tabular}

$*$, **, *** indicated at 5\%,1\% and 0.1\% level of significance, respectively. Days to 50\% anthesis (DA), Days to 50\% silking (DS), Anthesis Silking Interval (ASI), Plant height (PH), Ear height (EH), Days to maturity (DM), Number of tassels (NT), Cob circumference (CC), Cob length (CL), Number of seeds (NS), Thousand-seed weight (TSW) and Grain yield (GY). 
Table 3: Mean squares due to genotype, combining abilities and reciprocal on growth attributes, yield and its components in a 4 × full diallel cross of maize.

\begin{tabular}{|c|c|c|c|c|c|c|c|c|c|c|c|c|c|}
\hline $\begin{array}{c}\text { Sources of } \\
\text { variation } \\
\end{array}$ & df & $\begin{array}{c}\text { DA } \\
\text { (days) }\end{array}$ & $\begin{array}{c}\text { DS } \\
\text { (days) }\end{array}$ & $\begin{array}{c}\text { ASI } \\
\text { (days) }\end{array}$ & $\begin{array}{c}\text { PH } \\
(\mathrm{cm})\end{array}$ & $\begin{array}{r}\mathbf{E H} \\
(\mathrm{cm})\end{array}$ & $\begin{array}{c}\text { DM } \\
\text { (days) }\end{array}$ & NT & $\begin{array}{c}\mathrm{CC} \\
(\mathrm{cm})\end{array}$ & $\begin{array}{c}\mathrm{CL} \\
(\mathrm{cm})\end{array}$ & $\mathbf{N S}$ & $\begin{array}{c}\text { TSW } \\
(\mathrm{g})\end{array}$ & $\begin{array}{c}\text { GY } \\
(t / h)\end{array}$ \\
\hline Genotype & 15 & 7.817 **** & $16.296 * *$ & $8.396 *$ & 1769.149 *** & $365.641 * * *$ & $17.096 * *$ & $\begin{array}{c}75.329 \\
* * *\end{array}$ & $\begin{array}{c}2.515 \\
* * *\end{array}$ & $9.019 * *$ & $15603.450 * * *$ & $2826.324 * *$ & $1.548 *$ \\
\hline GCA & 3 & $0.578 \mathrm{~ns}$ & $7.594 * *$ & $2.313 \mathrm{~ns}$ & $1067.711 \mathrm{~ns}$ & $28.945 \mathrm{~ns}$ & $2.755 \mathrm{~ns}$ & $53.135 * *$ & $1.695 *$ & $2.935 \mathrm{~ns}$ & $4330.474 \mathrm{~ns}$ & $1147.807 \mathrm{~ns}$ & $\begin{array}{c}1.371 \\
* * *\end{array}$ \\
\hline SCA & 6 & $1.050 \mathrm{~ns}$ & $1.180 \mathrm{~ns}$ & $1.560 \mathrm{~ns}$ & 484.956 *** & $171.346 * * *$ & $1.537 \mathrm{~ns}$ & $\begin{array}{c}10.701 \\
* * *\end{array}$ & $0.498 * *$ & $2.850 * *$ & $3896.492 * *$ & $855.351 * *$ & $0.142 \mathrm{~ns}$ \\
\hline Reciprocal & 6 & $3.547 * * *$ & $5.208 *$ & $2.531 *$ & $86.907 \mathrm{~ns}$ & $42.707 \mathrm{~ns}$ & $7.771 * * *$ & $9.813 * * *$ & $0.226 \mathrm{~ns}$ & $1.319 \mathrm{~ns}$ & $3690.427 * *$ & $337.198 \mathrm{~ns}$ & $0.140 \mathrm{~ns}$ \\
\hline Error & 45 & 0.488 & 1.656 & 0.961 & 59.499 & 26.159 & 1.599 & 1.945 & 0.121 & 0.704 & 1087.455 & 232.738 & 0.196 \\
\hline GCA:SCA & & 0.551 & 6.436 & 1.483 & 2.202 & 0.169 & 1.793 & 4.965 & 3.404 & 1.030 & 1.111 & 1.342 & 9.655 \\
\hline
\end{tabular}

$*$, **, *** indicated at 5\%,1\% and $0.1 \%$ level of significance, respectively. Ns - not significant. Days to 50\% anthesis (DA), Days to 50\% silking (DS), Anthesis Silking Interval (ASI), Plant height (PH), Ear height (EH), Days to maturity (DM), Number of tassels (NT), Cob circumference (CC), Cob length (CL), Number of seeds (NS), Thousand-seed weight (TSW) and Grain yield (GY).

\subsection{Analysis of variance}

The mean performance on growth attributes, yield and its contributing traits of studied maize genotypes (parents, F1s and reciprocals) along with the check variety (Oba super II) are presented in Table 2. Significant differences were observed for all the characters, indicating sufficient genetic variability present among the maize genotypes. This F1 hybrid combination (PL2 x PL3) showed higher mean performance across most studied traits, as when compared to parents, other crosses and check variety.

Results in Table 3 revealed that both combining abilities (GCA and SCA) and reciprocal mean squares were significant for some studied traits. For GCA, days to silking, number of tassels, cob circumference and grain yield. On SCA, plant and ear heights, number of tassels, cob circumference and length, number of seeds and 1000-seed weight. While for reciprocal, days to anthesis and silking, anthesis silking interval, days to maturity, number of tassels and seeds. The findings indicated that both additive and non-additive types of gene effects were involved in the inheritance of those traits. The ratio of GCA/SCA was not less than unity for most studied traits excepted days to anthesis and ear height. It showed that the additive genetic effects were more important and played the key role in most of studied traits indicating that the additive gene was more imperative than non-additive gene action.
Analysis of variance for combining ability showed that estimates of mean squares due to gca, sca, and reciprocal were significant for some studied characters. This indicated importance of both additive and non-additive components of genetic variance in governing those traits. This was confirmed by Elmyhun et al. [48], Amiruzzaman et al. [49], and Derera et al. [50], who reported comparable results for yield and yield components in maize. The ratio of the components showed that gca variance was higher than sca for days to silking, anthesis silking interval, plant height, days to maturity, number of tassels, cob circumference and length, number of seeds, 1000-seed weight and grain yield (t.h-1) in Table 3. This indicated predominance of additive genetic variances for those traits. This finding was confirmed by Vasal et al. [51] and Mohammad et al. [52], who researched on combining ability and heterosis in maize and revealed that there is predominant additive genetic variance in the inheritance of traits in maize.

\subsection{General combining ability (GCA) effects}

The estimates of general combining ability effects of the parents are presented in Table 4. For days to anthesis and silking, significant negative estimates are considered desirable, indicating those associated with earliness. The parent, PL3 $(-1.4062 *)$ showed significant negative GCA effects only for days to silking. In plant and ear heights, significant negative estimates are 
Francis Chukwuma Onejeme et al., Int. Ann. Sci.; Vol. 9, Issue 1, pp: 188-200, 2020

desirable and seem to be correlated with dwarfism (short stature). Thus, PL4 (-16.7850*) was good combiner having significant negative GCA effects only for plant height. However, PL3 $(8.5881 *)$ was considered worst general combiner for the trait since positive significant difference leads to lodging incidence. For the number of tassels, significant positive estimates are desirable for abundant of pollen to be shed, indicating high percentage of ears getting fertilize. The PL2 (3.0312*) was best combiner with significant positive GCA effects for this trait. However, PL1 (-1.5312*) and PL3 (-2.6562*) were considered worst combiner having significant negative GCA effects for the same trait.

In addition, cob circumference and length, significant positive estimates are desirable towards quantity of seeds per cob. The PL2 $(0.6302 *)$ was good combiner with significant positive GCA effects only for cob circumference. However, PL1 $(-0.4480 *)$ was considered worst general combiner having significant negative GCA effects for same trait. The PL3 $\left(0.5814^{*}\right)$ was the best general combiner for grain yield and also possessed significant positive GCA effects, since it's an indicator for returns on investment $\left(\mathrm{t} . \mathrm{h}^{-1}\right)$.

Considering the trait(s) involved, estimates of general combining ability effects of the parents are considered desirable for significant negative and/or positive estimates. From the GCA effects, it was observed that, none of the parents individually showed good general combiner for all the studied traits. Nevertheless, significant negative estimate is desirable for days to anthesis and silking, anthesis silking interval, maturity, plant and ear heights. This finding was confirmed by Singh and Singh [53], Singh et al. [54], Ahmed et al. [55] and Mohammad et al. [52], who reported that earliness is linked with days to silk and the short plants with stumpy ear height are correlated with resistance to lodging. Whereas, significant positive estimate is desirable for number of tassels, cob circumference and length, number of seeds, 1000-seed weight (g) and grain yield (t.h-1). This was also supported by Singh et al. [54], Ahmed et al. [55] and Mohammad et al. [52].

Table 4: Estimates of general combining ability (GCA) effects on growth attributes, yield and its components in a $4 \times 4$ full diallel cross of maize.

\begin{tabular}{|c|c|c|c|c|c|c|c|c|c|c|c|c|}
\hline Parents & $\begin{array}{c}\text { DA } \\
\text { (days) }\end{array}$ & $\begin{array}{c}\text { DS } \\
\text { (days) }\end{array}$ & $\begin{array}{c}\text { ASI } \\
\text { (days) }\end{array}$ & $\begin{array}{l}\text { PH } \\
(\mathrm{cm})\end{array}$ & $\begin{array}{l}\text { EH } \\
(\mathrm{cm})\end{array}$ & $\begin{array}{c}\text { DM } \\
\text { (days) }\end{array}$ & NT & $\begin{array}{l}\mathrm{CC} \\
(\mathrm{cm})\end{array}$ & $\begin{array}{l}\text { CL } \\
(\mathrm{cm})\end{array}$ & $\mathbf{N S}$ & $\begin{array}{c}\text { TSW } \\
\text { (g) }\end{array}$ & $\begin{array}{l}\text { GY } \\
(\mathbf{t} / \mathbf{h})\end{array}$ \\
\hline PL1 (Obatamkpa) & 0.0312 & 0.6562 & 0.5625 & 1.7209 & -1.1670 & 0.5625 & $-1.5312 *$ & $-0.4480 *$ & -0.6531 & -31.2188 & -12.9139 & 0.0067 \\
\hline PL2 (Ikom white) & 0.3125 & 0.0938 & 0.3125 & 6.4759 & 2.4167 & 0.4062 & $3.0312 *$ & $0.6302 *$ & 0.7522 & -0.1250 & 13.9548 & -0.3336 \\
\hline PL3 (Oba 98) & - & $-1.4062 *$ & -0.6250 & $8.5881 *$ & -1.8230 & -0.6875 & $-2.6562 *$ & 0.0123 & 0.1778 & 24.5625 & 5.3267 & $0.5814 *$ \\
\hline PL4 (Oba super I) & -0.3438 & 0.6562 & -0.2500 & $-16.7850 *$ & 0.5733 & -0.2812 & 1.1562 & -0.1945 & -0.2769 & 6.7812 & -6.3677 & -0.2545 \\
\hline SE (gi) & 0.2139 & 0.3940 & 0.3001 & 2.3618 & 1.5660 & 0.3872 & 0.4271 & 0.1063 & 0.2568 & 10.0970 & 4.6711 & 0.1355 \\
\hline $\mathrm{SE}(\mathrm{gi}-\mathrm{gj})$ & 0.3494 & 0.6435 & 0.4901 & 3.8568 & 2.5573 & 0.6322 & 0.6974 & 0.1737 & 0.4194 & 16.4883 & 7.6279 & 0.2213 \\
\hline $\operatorname{LSD}(0.05)$ & 0.7036 & 1.2960 & 0.9871 & 7.7680 & 5.1506 & 1.2734 & 1.4046 & 0.3498 & 0.8448 & 33.2091 & 15.3633 & 0.4457 \\
\hline
\end{tabular}

* indicated at 5\% level of significance. Days to 50\% anthesis (DA), Days to 50\% silking (DS), Anthesis Silking Interval (ASI), Plant height (PH), Ear height (EH), Days to maturity (DM), Number of tassels (NT), Cob circumference (CC), Cob length (CL), Number of seeds (NS), Thousand-seed weight (TSW) and Grain yield (GY). 
Table 5: Estimates of specific combining ability (SCA) effects on growth attributes, yield and its components in a $4 \times 4$ full diallel cross of maize.

\begin{tabular}{|c|c|c|c|c|c|c|c|c|c|c|c|c|}
\hline $\begin{array}{l}\text { Crosses } \\
\text { (F1's) }\end{array}$ & $\begin{array}{c}\text { DA } \\
\text { (days) }\end{array}$ & $\begin{array}{c}\text { DS } \\
\text { (days) }\end{array}$ & $\begin{array}{c}\text { ASI } \\
\text { (days) }\end{array}$ & $\begin{array}{c}\text { PH } \\
(\mathrm{cm})\end{array}$ & $\begin{array}{c}\text { EH } \\
(\mathbf{c m})\end{array}$ & $\begin{array}{c}\text { DM } \\
\text { (days) }\end{array}$ & NT & $\begin{array}{c}\mathrm{CC} \\
(\mathrm{cm})\end{array}$ & $\begin{array}{c}\text { CL } \\
(\mathrm{cm})\end{array}$ & NS & $\begin{array}{c}\text { TSW } \\
\text { (g) }\end{array}$ & $\begin{array}{c}\text { GY } \\
(t / h)\end{array}$ \\
\hline$\overline{\text { PL1 x PL2 }}$ & $-1.0312 *$ & 0.5312 & 1.0312 & $15.1584 *$ & $9.7711 *$ & -1.0625 & 1.0938 & -0.0867 & -0.4044 & 19.1562 & -8.0205 & -0.2111 \\
\hline PL1 x PL3 & -0.2188 & 0.0312 & -0.5312 & 5.7525 & 1.1758 & -0.3438 & -0.0938 & 0.1148 & 0.4950 & 17.8438 & 5.0827 & 0.0814 \\
\hline PL1 x PL4 & 0.5000 & -0.4062 & 0.3438 & -5.0731 & 0.4058 & 0.8750 & 1.3438 & 0.2705 & 0.6684 & 13.1250 & 9.7520 & 0.1811 \\
\hline PL2 x PL3 & $1.0000 *$ & -0.7812 & -0.7812 & $16.7463 *$ & $8.3033 *$ & 0.3125 & 0.8438 & $0.6967 *$ & $1.7659 *$ & $55.2500 *$ & 19.5014 & 0.4517 \\
\hline PL2 x PL4 & -0.4062 & -0.9688 & 0.0938 & -3.1394 & -0.3042 & -0.0938 & 0.5312 & 0.2323 & 0.5431 & 17.4062 & $25.8708 *$ & -0.1198 \\
\hline PL3 x PL4 & -0.3438 & 0.2812 & 1.0312 & 2.5734 & 4.3942 & 0.7500 & $2.5938 *$ & 0.0052 & -0.4225 & -36.1562 & -7.0886 & -0.0623 \\
\hline SE (sij) & 0.3906 & 0.7194 & 0.5479 & 4.3120 & 2.8591 & 0.7069 & 0.7797 & 0.1942 & 0.4689 & 18.4345 & 8.5282 & 0.2474 \\
\hline $\mathrm{SE}(\mathrm{sij}-\mathrm{skl})$ & 0.4941 & 0.9100 & 0.6931 & 5.4543 & 3.6165 & 0.8941 & 0.9862 & 0.2456 & 0.5932 & 23.3180 & 10.7874 & 0.3129 \\
\hline LSD (0.05) & 0.9951 & 1.8329 & 1.3960 & 10.9855 & 7.2841 & 1.8009 & 1.9864 & 0.4946 & 1.1947 & 46.9648 & 21.7270 & 0.6302 \\
\hline
\end{tabular}

* indicated at 5\% level of significance. Days to 50\% anthesis (DA), Days to 50\% silking (DS), Anthesis Silking Interval (ASI), Plant height (PH), Ear height (EH), Days to maturity (DM), Number of tassels (NT), Cob circumference (CC), Cob length (CL), Number of seeds (NS), Thousand-seed weight (TSW) and Grain yield (GY).

\subsection{Specific combining ability (SCA) effects}

The SCA effects of the crosses (F1s) for twelve characters are presented in Table 5. For days to anthesis and silking, this F1 single hybrid cross PL1 x PL2 (-1.0312*) exhibited significant negative SCA effects for anthesis, indicating early pollen shedding of the hybrid. However, cross PL2 x PL3 $(1.0000 *)$ had significant positive SCA effects on days to anthesis, indicating late pollen shedding of the hybrid. The SCA effects of these crosses PL1 x PL2 (15.1584* and 9.7711 *) and PL2 x PL3 (16.7463* and $8.3033 *$ ) were significant positive for both plant and ear heights respectively, indicating lodging incidence of the hybrids. For the number of tassels, cross PL3 $\mathrm{x}$ PL4 $(2.5938 *)$ showed significant positive SCA effects, indicating abundant of pollen to be shed by the hybrid.

On the yield and yield components, among six hybrid crosses, this cross PL2 x PL3 (0.6967*, $1.7659 *$ and $55.2500 *$ ) revealed significant positive SCA effects for cob circumference, cob length and number of seeds respectively (Table 5) and also possessed high mean values for the most of aforementioned same traits in Table 2, indicating farmer's preferred hybrid cross for returns on investment $\left(\mathrm{t} \cdot \mathrm{h}^{-1}\right)$. Further, out of six crosses, this cross PL2 x PL4 (25.8708*) showed significant positive SCA effects for 1000-seed weight $(\mathrm{g})$.

The significant SCA effects could be desirable for positive and/or negative estimates. The parents involved where one or both the parental lines were allied to good combiners, indicating GCA of the parental lines play major role for high performance. This study revealed that some crosses were preferred over others based on the direction of desirability. Significant negative estimate is desirable and observed for days to anthesis, plant and ear heights. While significant positive estimate is desirable for number of tassels, cob circumference and length, number of seeds, and 1000-seed weight (g). This results was supported by Fan et al. [56] and Mohammad et al. [52]. The crosses also possessed high per se performances in some studied characters (Table 2). Vasal [40] supported the findings with a suggestion to include one good combiner, especially female parent during crossing to attain higher heterosis. Generally, the gca effects of the parents were reflected in the sca effects of the crosses in most of the studied traits. This was confirmed with the findings of Gowda et al. [57], Gissa et al. [58], and Ahmed et al. [55], who obtained high estimates of sca from high gca parents.

\subsection{Reciprocal effects}

Maternal effects and sex-linkage give rise to differences among reciprocal crosses. In diallel cross analyses, the presence of these effects will cause biases in the estimates of genotypic components of the variation. The estimates of specific ( $\mathrm{r}$ ij) combining ability effects of the six hybrid combinations over twelve studied characters are presented in Table 6. For days to anthesis and maturity, this cross PL3 x PL2 $(3.0000 *$ and $4.1250 *)$ showed significant 
Francis Chukwuma Onejeme et al., Int. Ann. Sci.; Vol. 9, Issue 1, pp: 188-200, 2020

positive ( $r$ ij) effects, an indicator for late pollen shedding and delay maturity of the hybrid respectively. On the number of tassels, this cross PL4 $\times$ PL2 $(-5.1250 *)$ showed significant negative (r ij) effects. For the number of seeds, cross PL2 x PL1 (-79.6250*) had significant negative ( $r$ ij) effects. Therefore, such combinations are to be dictated and discarded while considering of their SCA (F1s) effects in the breeding programs for better hybrids.

The significant positive or negative reciprocal effects for the studied traits were not desirable and found lower than those for SCA, which indicated that there is a difference between using a line as a male or a female in the same cross. This was supported with findings by Abdel-Moneam et al. [59], who revealed that the SCA effects were usually higher than those of reciprocal effects in field maize. However, this results was not consistent with reports by Moterle et al. [60] and Cabral et al. [61], who found greater effects for reciprocal than SCA.

Table 6: Estimates of reciprocal effects on growth attributes, yield and its components in a $4 \times 4$ full diallel cross of maize.

\begin{tabular}{|c|c|c|c|c|c|c|c|c|c|c|c|c|}
\hline $\begin{array}{l}\text { Crosses } \\
\text { (Reciprocals) }\end{array}$ & $\begin{array}{c}\text { DA } \\
\text { (days) }\end{array}$ & $\begin{array}{c}\text { DS } \\
\text { (days) }\end{array}$ & $\begin{array}{c}\text { ASI } \\
\text { (days) }\end{array}$ & $\begin{array}{l}\text { PH } \\
(\mathrm{cm})\end{array}$ & $\begin{array}{l}\text { EH } \\
(\mathrm{cm})\end{array}$ & $\begin{array}{c}\text { DM } \\
\text { (days) }\end{array}$ & NT & $\begin{array}{l}\mathrm{CC} \\
(\mathrm{cm})\end{array}$ & $\begin{array}{l}\text { CL } \\
(\mathrm{cm})\end{array}$ & NS & $\begin{array}{c}\text { TSW } \\
(\mathrm{g})\end{array}$ & $\begin{array}{l}\text { GY } \\
(t / h)\end{array}$ \\
\hline PL2 x PL1 & 0.5000 & 2.1250 & 1.6250 & -7.4162 & -3.2075 & 0.5000 & 0.5000 & -0.6800 & -1.5525 & -79. & 11.0375 & 0.4375 \\
\hline PL3 x PL1 & 0.2500 & 1.1250 & 0.8750 & -2.7925 & -5.3750 & 1.1250 & -1.3750 & -0.2637 & -1.0000 & -5.5000 & -6.5125 & 0.0925 \\
\hline PL3 x PL2 & $3.0000 *$ & 2.2500 & 1.6250 & 10.2912 & 8.4988 & $4.1250 *$ & 0.1250 & -0.0163 & 0.4062 & 24.7500 & 9.5250 & 0.0850 \\
\hline PL4 x PL1 & 1.1250 & 2.0000 & 0.8750 & -9.5363 & -0.8338 & 2.0000 & -0.1250 & -0.2100 & -0.2588 & 9.0000 & -25.4875 & 0.2637 \\
\hline PL4 x PL2 & 0.2500 & 0.1250 & -0.1250 & 0.9775 & -3.8750 & 0.1250 & $-5.1250 *$ & -0.1425 & 0.4162 & 63.1250 & -10.3000 & -0.2650 \\
\hline PL4 x PL3 & - & -0.8750 & -0.8750 & 0.3400 & -1.0012 & -0.8750 & 1.0000 & 0.2825 & -0.3762 & -4.7500 & 0.9625 & -0.2700 \\
\hline SE (rij) & 0.4941 & 0.9100 & 0.6931 & 5.4543 & 3.6165 & 0.8941 & 0.9862 & 0.2456 & 0.5932 & 23.3180 & 10.7874 & 0.3129 \\
\hline SE (rij - rkl) & 0.6987 & 1.2870 & 0.9802 & 7.7136 & 5.1146 & 1.2645 & 1.3947 & 0.3473 & 0.8388 & 32.9766 & 15.2557 & 0.4425 \\
\hline $\mathrm{SD}(0.05)$ & 1.4073 & 2.5921 & 1.9742 & 15.5359 & 10.3012 & 2.5468 & 2.8092 & 0.6995 & 1.6895 & 66.4182 & 30.7266 & 0.8913 \\
\hline
\end{tabular}

* indicated at 5\% level of significance. Days to 50\% anthesis (DA), Days to 50\% silking (DS), Anthesis Silking Interval (ASI), Plant height $(\mathrm{PH})$, Ear height (EH), Days to maturity (DM), Number of tassels (NT), Cob circumference (CC), Cob length (CL), Number of seeds (NS), Thousand-seed weight (TSW) and Grain yield (GY).

Table 7: Percent heterosis of the hybrid combinations over the check variety (Oba super II) on growth attributes, yield and its components in a $4 \times 4$ full diallel cross.

\begin{tabular}{|c|c|c|c|c|c|c|c|c|c|c|c|c|}
\hline Crosses & $\begin{array}{c}\text { DA } \\
\text { (days) }\end{array}$ & $\begin{array}{c}\text { DS } \\
\text { (days) }\end{array}$ & $\begin{array}{c}\text { ASI } \\
\text { (days) }\end{array}$ & $\begin{array}{c}\text { PH } \\
(\mathrm{cm})\end{array}$ & $\begin{array}{c}\text { EH } \\
(\mathbf{c m})\end{array}$ & $\begin{array}{c}\text { DM } \\
\text { (days) }\end{array}$ & NT & $\begin{array}{c}\mathrm{CC} \\
(\mathrm{cm})\end{array}$ & $\begin{array}{c}\text { CL } \\
(\mathrm{cm})\end{array}$ & NS & $\begin{array}{c}\text { TSW } \\
(\mathrm{g})\end{array}$ & $\begin{array}{c}\text { GY } \\
(\mathbf{t} / \mathbf{h})\end{array}$ \\
\hline PL1 x PL2 & 0.00 & $4.82 * *$ & $52.17 * *$ & -4.07 & 4.51 & -0.18 & $11.11 * *$ & $-2.09 * *$ & $-16.02 * *$ & -29.10 & 10.52 & $6.64 * *$ \\
\hline PL1 x PL3 & 0.44 & 0.00 & $-4.35 * *$ & -5.23 & $-12.83 *$ & 0.00 & $-27.78 * *$ & $-2.09 * *$ & $-10.58 * *$ & -10.03 & 4.13 & $22.08 * *$ \\
\hline PL1 x PL4 & $2.66 * *$ & $4.02 *$ & $17.39 * *$ & $-23.83 *$ & -5.67 & 1.76 & 1.11 & $-2.09 * *$ & $-7.73 * *$ & -11.60 & -8.65 & $12.03 * *$ \\
\hline PL2 x PL1 & $-1.77 *$ & -2.01 & $-4.35 * *$ & 2.34 & 11.91 & -0.88 & $6.67 * *$ & $7.39 * *$ & $3.22 * *$ & 2.05 & -0.30 & $-8.98 * *$ \\
\hline PL2 x PL3 & $7.97 * *$ & -0.40 & 0.00 & 7.22 & $15.61 *$ & 2.46 & $3.33 *$ & $11.23 * *$ & $14.66 * *$ & 9.29 & 32.30 & $22.62 * *$ \\
\hline PL2 x PL4 & 0.00 & -0.80 & $-8.70 * *$ & -16.39 & -5.90 & -0.35 & $-4.44 *$ & $5.65 * *$ & $4.39 * *$ & 5.91 & 19.91 & $-8.98 * *$ \\
\hline PL3 x PL1 & -0.44 & $-3.62 *$ & $-34.78 * *$ & -2.81 & -0.35 & -1.58 & $-15.56 * *$ & $1.60 * *$ & 1.79 & -7.88 & 10.52 & $18.85 * *$ \\
\hline PL3 x PL2 & $-2.66 * *$ & $-7.63 * *$ & $-56.52 * *$ & -1.69 & -4.05 & $-3.34 *$ & 2.22 & $11.44 * *$ & $9.65 * *$ & -0.41 & 22.91 & $19.57 * *$ \\
\hline PL3 x PL4 & -0.89 & -2.81 & $-21.74 * *$ & -13.28 & -2.08 & -1.23 & $6.67 * *$ & $2.72 * *$ & $-10.08 * *$ & -13.01 & 5.02 & $8.44 * *$ \\
\hline PL4 x PL1 & -1.33 & -2.41 & $-13.04 * *$ & -15.57 & -3.82 & -1.06 & 2.22 & $0.84 *$ & $-4.52 * *$ & -15.12 & 16.37 & $2.51 * *$ \\
\hline PL4 x PL2 & -0.89 & -1.21 & $-4.35 * *$ & -17.22 & 3.12 & -0.53 & $41.11 * *$ & 0.70 & -0.80 & -18.80 & 30.04 & 0.54 \\
\hline PL4 x PL3 & -0.89 & 0.00 & $8.70 * *$ & -13.54 & 0.23 & 0.00 & -2.22 & $-1.19 * *$ & $-5.44 * *$ & -11.15 & 4.08 & $18.13 * *$ \\
\hline Mean & 0.18 & -1.00 & -5.80 & -8.67 & 0.06 & -0.41 & 2.04 & 2.84 & -1.79 & -8.32 & 12.24 & 9.45 \\
\hline Minimum & -2.66 & -7.63 & -56.52 & -23.83 & -12.83 & -3.34 & -27.78 & -2.09 & -16.02 & -29.10 & -8.65 & -8.98 \\
\hline Maximum & 7.97 & 4.82 & 52.17 & 7.22 & 15.61 & 2.46 & 41.11 & 11.44 & 14.66 & 9.29 & 32.30 & 22.62 \\
\hline CD (0.05) & 1.66 & 3.01 & 2.32 & 17.91 & 12.65 & 2.94 & 3.26 & 0.82 & 1.95 & 77.58 & 37.40 & 1.03 \\
\hline CD (0.01) & 2.39 & 4.32 & 3.33 & 25.72 & 18.17 & 4.22 & 4.68 & 1.18 & 2.80 & 111.43 & 53.71 & 1.47 \\
\hline
\end{tabular}

*, ** indicated at 5\% and 1\% level of significance, respectively. Days to 50\% anthesis (DA), Days to 50\% silking (DS), Anthesis Silking Interval (ASI), Plant height (PH), Ear height (EH), Days to maturity (DM), Number of tassels (NT), Cob circumference (CC), Cob length (CL), Number of seeds (NS), Thousand-seed weight (TSW) and Grain yield (GY). 


\subsection{Heterosis}

The standard heterosis expressed by the F1 hybrids (including reciprocals) over the commercial check variety (Oba super II) for different characters are presented in Table 7 . The percent heterosis in F1 hybrids varied from character to character and also cross to cross.

Days to anthesis and silking determine the earliness of flowering of the hybrids. Negative heterosis is desirable for these characters. Considering commercial hybrid Oba super II as a check, these crosses PL2 x PL1 (-1.77*) and PL3 x PL2 $\left(-2.66^{* *}\right)$ showed significant negative heterosis for days to anthesis and ranged from 2.66 to $7.97 \%$. For days to silking, these crosses PL3 x PL1 (-3.62*) and PL3 x PL2 (-7.63**) also showed significant negative heterosis and ranged from -7.63 to $4.82 \%$ (Table 7). However, all the significant positive heterosis for same traits are not desirable. Consequently, anthesis silking interval had both positive and negative significant heterosis on almost the studied hybrids and ranged from -56.52 to $52.17 \%$. Thus, eight hybrid crosses PL1 x PL3 (-4.35 **), PL2 x PL1 (-4.35 **), PL2 x PL4 (-8.70 **), PL3 x PL1 (-34.78**), PL3 x PL2 $(-56.52 * *)$, PL3 x PL4 $(-21.74 * *)$, PL4 x PL1 (-13.04**) and PL4 x PL2 (-4.35**) showed significant negative heterosis. However, the rest of hybrid crosses with significant positive heterosis are considered not desirable. Negative heterosis is also desirable for days to maturity which aids for adjusting cropping pattern. Considering commercial hybrid Oba super II as a check, this cross PL3 x PL2 $(-3.34 *)$ expressed significant negative heterosis (Table 7). The days to maturity ranged from -3.34 to $2.46 \%$.

Negative heterosis is desirable for plant and ear heights which helps for developing short statured plant leads to lodging resistance. Considering commercial hybrid Oba super II as a check, this cross PL1 x PL4 (-23.83*) exhibited significant negative heterosis for plant height which indicates dwarfness of the hybrid (Table 7). For ear height, this cross PL1 x PL3 $(-12.83 *)$ showed significant negative heterosis and another cross PL2 x PL3 (15.61 *) had significant positive heterosis, indicates not desirable.
Therefore, plant and ear heights produced ranged from -23.83 to $7.22 \%$ and -12.83 to $15.61 \%$ respectively. For the number of tassels, positive heterosis is desirable. Among twelve hybrid crosses, five crosses PL1 x PL2 (11.11 **), PL2 x PL1 $\left(6.67^{* *}\right)$, PL2 x PL3 $\left(3.33^{*}\right)$, PL3 x PL4 $\left(6.67^{* *}\right)$ and PL4 $x$ PL2 (41.11**) showed significant positive heterosis and ranged from 27.78 to $41.11 \%$. Further, the percent heterosis for cob circumference and length varied from 2.09 to $11.44 \%$ and -16.02 to $14.66 \%$ respectively. The results showed that among the twelve hybrid combinations, seven crosses PL2 $\mathrm{x}$ PL1 (7.39 **), PL2 x PL3 (11.23 **), PL2 x PL4 (5.65**), PL3 x PL1 (1.60**), PL3 x PL2 (11.44 **), PL3 x PL4 (2.72**), and PL4 x PL1 (0.84*) exhibited significant positive heterosis for cob circumference. And four crosses PL2 x PL1 (3.22 **), PL2 x PL3 (14.66 **), PL2 x PL4 (4.39**) and PL3 $x$ PL2 $\left(9.65^{* *}\right)$ revealed significant positive heterosis for cob length (Table 7).

Positive heterosis is desirable for grain yield (t.h1) which shows better returns on investment. Considering commercial hybrid Oba super II as a check, nine hybrid crosses PL1 x PL2 (6.64 **), PL1 x PL3 (22.08 **), PL1 x PL4 (12.03 **), PL2 x PL3 $(22.62 * *)$, PL3 x PL1 (18.85 **), PL3 x PL2 (19.57 **), PL3 x PL4 (8.44 **), PL4 x PL1 $\left(2.51^{* *}\right)$ and PL4 x PL3 $\left(18.13^{* *}\right)$ showed significant positive heterosis. However, few crosses had significant negative heterosis, indicate not desirable on perception of farmer's preferred varieties. The percent heterosis for grain yield $\left(\mathrm{t} . \mathrm{h}^{-1}\right)$ ranged from -8.98 to $22.62 \%$.

The standard heterosis showed by F1 hybrid combinations for respective trait desirability ranged from significant negative to positive results. This shows that those desired F1 hybrid combinations are better than the commercial check variety and should be considered in breeding programs for higher yield. This was confirmed with the results by Mohammad et al. [52], Uddin et al. [62], Uddin et al. [63], and Atif et al. [64]. They reported that F1 hybrids were better than check varieties studied. 


\section{Conclusion}

The overall study of GCA effects suggest that PL3 was excellent general combiner for early silking and grain yield, PL4 was excellent for shorter height, and PL2 for pollen shed and cob circumference. These parents could be used in future breeding programmes to improve maize yield with desirable traits. This cross (PL2 x PL3) showed the most desired heterosis for yields compared to the check (Oba super II). The cross combinations (PL1 x PL2, PL2 x PL3, PL2 x PL4 and PL3 $x$ PL4) exhibited significant high SCA effects coupled with per se performance could be more rewarding in a hybrid breeding program after thorough research at different agro ecological zones.

\section{Declarations}

\subsection{Acknowledgement}

The authors acknowledge the Department of Crop Science and Horticulture, Nnamdi Azikiwe University, Awka for the enabling environment provided.

\subsection{Competing Interests}

The authors declare no conflicts of interest.

\section{How to Cite this Article:}

F. Onejeme, E. Okporie, and C. Eze, "Combining Ability and Heterosis in Diallel Analysis of Maize (Zea mays L.) Lines", Int. Ann. Sci., vol. 9, no. 1, pp. 188-200, Jul. 2020. https://doi.org/10.21467/ias.9.1.188-200

\section{References}

[1] S. K. Assem, "Maize, Tropical (Zea mays L.)," Methods Mol. Biol., vol. 1223, pp. 119-134, 2015. DOI: 10.1007/978-1-4939-1695-5-9.

[2] A. A. Abdulrahaman and O. M. Kolawole, "Traditional preparations and uses of maize in Nigeria," Ethnobotanical Leaflets, vol. 10, pp. 219-227, August 2006.

[3] S. Dutt, "A handbook of Agriculture," ABD Publishers, India, pp. 116-118, January 2005. ISBN-10: 9788189011543.

[4] A. E. Sharief, S. E. El-Kalla, H. E. Gado and H. A. E. Abo-Yousef, "Heterosis in yellow maize," Aust. J. Crop Sci., vol. 3, no. 3, pp. 146-154, May 2009. ISSN: 18352707.

[5] B. Griffing, "Concept of general and specific combining ability in relation to diallel crossing systems," Aust. J. Biol. Sci., vol. 9, no. 4, pp. 463-493, June 1956.

[6] C. O. Gardner and S. A. Eberhart, "Analysis and interpretation of the variety cross diallel and related populations," Biometrics, vol. 22, no. 3, pp. 439-452, September 1966
[7] T. Shimelis, Z. Habtamu and A. Demissew, "Combining ability of highland adapted maize (Zea mays L.) inbred lines for grain yield and yield related traits under optimum and low nitrogen conditions," African J. Plant Sci., vol. 13, no. 5, pp. 125-137, May 2019. https://doi.org/10.5897/AJPS2019.1765.

[8] A. Menkir, A. Melake-Berhan, C. The, I. Ngelbrecht and A. Adepoju, "Grouping of tropical mid-altitude maize inbred lines on the basis of yield data and molecular markers," Theor. Applied Genetics, vol. 108, no. 8, pp. 1582-1590, May 2004. DOI: 10.1007/s00122-004-15850.

[9] M. D. Melani and M. D. Carena, "Alternative maize heterotic pattern for the Northern corn-belt," Crop Sci., vol. 45, no. 6, pp. 2186-2194, November 2005. https://doi.org/10.2135/cropsci2004.0289.

[10] C. Barata and M. J. Carena, "Classification of North Dakota maize inbred lines into heterotic groups based on molecular and testcross data," Euphytica, vol. 151, pp. 339-349, August 2006.

[11] B. A. Rojas and G. F. Sprague, "A comparison of variance components in com yield trials: III. General and specific combining ability and their interaction with locations and years," Agron. J., vol. 44, pp. 462-462, September 1952.

[12] D. Charlesworth and J. H. Willis, "The genetics of inbreeding depression," Nature Reviews Genetics, vol. 10, no. 11, pp. 783-796, November 2009.

[13] A. F. Troyer, "Adaptedness and heterosis in corn and mule hybrids," Crop Sci., vol. 46, no. 2, pp. 528-543, March 2006. https://doi.org/10.2135/cropsci2005.0065.

[14] C. G. Hopkins, "Inbreeding of corn and methods of prevention," Journal of Heredity, vol. os-1, no. 2, pp. 147-150, January 1905. https://doi.org/10.1093/jhered/os-1.2.147.

[15] G. H. Shull, "The composition of a field of maize," Journal of Heredity, vol. os-4, no. 1, pp. 296-301, January 1908. https://doi.org/10.1093/jhered/os-4.1.296.

[16] G. H. Shull, "A pure-line method in corn breeding," Journal of Heredity, vol. os-5, no. 1, pp. 51-58, January 1909. https://doi.org/10.1093/jhered/os-5.1.51.

[17] M. Frisch, A. Thiemann, J. Fu, T. A. Schrag, S. Scholten and A. E. Melchinger, "Transcriptome-based distance measures for grouping of germplasm and prediction of hybrid performance in maize," Theor. Applied Genetics, vol. 120, no. 2, pp. 441-450, November 2010. https://doi.org/10.1007/s00122-009-1204-1.

[18] C. Riedelsheimer, A. Czedik-Eysenberg, C. Grieder, J. Lisec, F. Technow and R. Sulpice et al., "Genomic and metabolic prediction of complex heterotic traits in hybrid maize," Nat. Genetics, vol. 44, no. 2, pp. 217-220, January 2012. https://doi.org/10.1038/ng.1033

[19] M. Groszmann, I. K. Greaves, Z. I. Albertyn, G. N. Scofield, W. J. Peacock and E. S. Dennis, "Changes in 24-nt siRNA levels in Arabidopsis hybrids suggest an epigenetic contribution to hybrid vigor," Proc. Natl. Acad. Sci. USA, vol. 108, no. 6, pp. 2617-2622, February 2011. https://doi.org/10.1073/pnas.1019217108.

[20] L. Zhang, Y. Peng, X. Wei, X. Y. Dia, D. Yuan and Y. $\mathrm{Lu}$ et al., "Small RNAs as important regulators for the hybrid vigour of super-hybrid rice," J. Exp. Bot., vol. 65, no, 20, pp. 5989-6002, November 2014. https://doi.org/10.1093/jxb/eru337.

[21] E. L. F. de Abreu, M. Westhues, A. cuadros-Inostroza, L. Wilmitzer, A. E. Melchinger and Z. Nikoloski, "Metabolic robustness in young roots underpins a 
predictive model of maize hybrid performance in the field," Plant J., vol. 90, pp. 319-329, January 2017. https://doi.org/10.1111/tpi.13495

[22] D. Dahal, B. P. Mooney and K. J. Newton, "Specific changes in total and mitochondrial proteomes are associated with higher levels of heterosis in maize hybrids." Plant J. vol. 72, no. 1, pp. 70-83, May 2012. https://doi.org/10.1111/j.1365-313x2012.05056.x

[23] P. S. Schnable and N. M. Springer, "Progress toward understanding heterosis in crop plants," Annual Review of Plant Biology, vol. 64, no. 1, pp. 71-88, April 2013. https://doi.org/10.1146/annurev-arplant-042110-103827

[24] S. Kaeppler, "Heterosis: Many genes, many mechanisms - End the search for an undiscovered unifying theory," ISRN Botany, vol. 2012, pp. 1-12, October 2012. https://doi.org/10.5402/2012/682824.

[25] S. A. Flint-Garcia, E. S. Buckler, P. Tiffin, E. Ersoz and N. M. Springer, "Heterosis is prevalent for multiple traits in diverse maize germplasm," PLoS One, vol. 4, no. 10, pp. 7433, October 2009. https://doi.org/10.1371/journal.pone.0007433

[26] M. Groszmann, R. Gonzalez-Bayon, R. L. Lyons, I. K. Greaves, K. Kazan and W. J. Peacock et al., "Hormoneregulated defense and stress response networks contribute to heterosis in Arabidopsis F1 hybrids." Proc. Natl. Acad. Sci. USA, vol. 112, no. 46, pp. 6397-6406, November 2015. https://doi.org/10.1073/pnas.1519926112.

[27] M. Miller, Q. Song, X. Shi, T. E. Juenger and Z. J. Chen, "Natural variation in timing of stress-responsive gene expression predicts heterosis in intraspecific hybrids of Arabidopsis," Natural Commun., vol. 6, pp. 7453, July 2015. https://doi.org/10.1038/ncomms8453. PMID: 26154604.

[28] F. Kutka, "Open-pollinated vs. hybrid maize cultivars," Sustainability, vol. 3, pp. 1531-1554, September 2011. DOI: 10.3390/su3091531. ISSN 2071-1050.

[29] U. Krieger, Z. B. Lippman and D. Zamir, "The flowering gene SINGLE FLOWER TRUSS drives heterosis for yield in tomato," Nat. Genetics, vol. 42, pp. 459-463, March 2010. https://doi.org/10.1038/ng.550. ISSN: 1546-1718.

[30] A. Girke, A. Schierholt and H. C. Becker, "Extending the rapeseed gene pool with resynthesized Brassica napus II: Heterosis," Theor. Appl. Genetics, vol. 124, no. 6, pp. 1017-1026, April 2012. https://doi.org/10.1007/s00122011-1765-7. PMID: 22159759.

[31] G. J. Seiler, L. L. L. Qi and L. F. Marek, "Utilization of sunflower crop wild relatives for cultivated sunflower improvement," Crop Sci., vol. 57, no. 3, pp. 1083-1101, June 2017. https://doi.org/10.2135/cropsci2016.10.0856.

[32] D. Li, Z. Huang, S. Song, Y. Xin, D. Mao, Q. Lv, M. Zhou, D. Tian, M. Tang, Q. Wu, X. Liu, T. Chen, X. Song, X. Fu, B. Zhao, C. Liang, A. Li, G. Liu, S. Li, S. $\mathrm{Hu}, \mathrm{X}$. Cao, J. Yu, L. Yuan, C. Chen and L. Zhu, "Integrated analysis of phenome, genome, and transcriptome of hybrid rice uncovered multiple heterosis-related loci for yield increase," Proc. Natl. Acad. Sci. USA, vol. 113, no. 41, pp. 6026-6035, September 2016. https://doi.org/10.1073/pnas.1610115113

[33] J. Tang, J. Yan, X. Ma, W. Teng, W. Wu, J. Dai, B. S. Dhillon, A. E. Melchinger and J. Li, "Dissection of the genetic basis of heterosis in an elite maize hybrid by QTL mapping in an immortalized F2 population," Theor. Appl. Genetics, vol. 120, no. 2, pp. 333-340, January
2010. https://doi.org/10.1007/s00122-009-1213-0. PMID: 19936698.

[34] T. Guo, N. Yang, H. Tong, Q. Pan, X. Yang, J. Tang, J. Wang, J. Li and J. Yan, "Genetic basis of grain yield heterosis in an "immortalized F2" maize population," Theor. Appl. Genetics, vol. 127, no. 10, pp. 2149-2158, October 2014b. https://doi.org/10.1007/s00122-0142368-x. PMID: 25104328.

[35] G. M. He, A. A. Elling and X. W. Deng, "The epigenome and plant development," Annnu Rev. Plant Biol., vol. 62, pp. 411-435, March 2011. https://doi.org/10.1146/annurev-arplant-042110103806.

[36] M. Groszmann, I. K. Greaves, R. Fujimoto, W. J. Peacock and E. S. Dennis, "The role of epigenetics in hybrid vigour," Trends Genetics, vol. 29, no. 12, pp. 684690, December 2013. https://doi.org/10.1016/j.tig.2013.07.004. PMID: 23953922

[37] I. K. Greaves, R. Gonzalez-Bayon, L. Wang, A. Y. Zhu, P. C. Liu, M. Groszmann, W. J. Peacock and E. S. Dennis, "Epigenetic changes in hybrids," Plant Physiol., vol. 168, no. 4, pp. 1197-1205, August 2015. https://doi.org/10.1104/pp.15.00231. PMID: 26002907.

[38] FAOSTAT, "Statistical databases and data sets of the Food and Agriculture Organization of the United Nations," Rome, September 2010.

[39] M. R. Rosegrant, C. Ringler, T. B. Sulser, Palazzo et al. and M. Ewing, "Agriculture and food security under global change: Prospects for 2025/2050," International Food Policy Research Institute, October 2009.

[40] S. K. Vasal, "Hybrid maize technology: Challenges and expanding possibilities for research in the next century, In: S. K. Vasal, C. F. Gonzalez and F. Xingming (ed), Proc. $7^{\text {th }}$ Asian Reg. Maize Workshop, Los Banos, Philippines,” pp. 58-62, February 1998.

[41] L. C. Mba and R. N. C. Anyadike, "Effect of soil characteristics on plant growth and productivity in Nsukka agro-ecological zone of Nigeria," International Journal of Research in Arts and Social Sciences, vol. 5, pp. 274-285, 2013. Corpus ID-132824339 ISSN-21418349.

[42] W. Ubi, G. M. Ubi, M. W. Ubi, T. Okweche and P. W. Ojei, "Optimizing NPK fertilizer and plant spacing in maximizing yield and yield attributes of maize (Zea mays) in southern Nigeria," Direct Res. J. Agric. Food Sci., vol. 4, no. 8, pp. 208-213, August 2016. ISSN 23544147.

[43] GenStat. GenStat 4th Edition, "VSN International bioscience software and consultancy," Hemel Hempstead, HP2 4TP UK, $4^{\text {th }}$ Edition, February, 2012. http://www.vsni.co.uk/about-vsni/press-andmedia/genstat.

[44] R. K. Singh and P. K. Singh, "A manual on genetics and plant breeding. Experimental techniques," Kalyani Publs. Ludiana, New Delhi, pp. 99-107, 1994. OCLC Number-726816058.

[45] J. R. Landon, "Booker tropical soil manual: A handbook for soil survey and agricultural land evaluation in the tropics and subtropics," John Wiley and sons Inc., New York, pp. 74, 1991. ISBN 13: 978-0-582-00557-0.

[46] FAO, "From work of land evaluation," FAO Bulletin 32, FAO UNESCO, Rome, 1976. ISBN 92-5-100111-1.

[47] O. Unamba, "The potassium status of the sand soils of Northern Imo State, Nigeria," J. Soil Sci., vol. 139, no. 5, pp. 437-445, May 1985. 
Francis Chukwuma Onejeme et al., Int. Ann. Sci.; Vol. 9, Issue 1, pp: 188-200, 2020

[48] M. Elmyhun, C. Liyew, A. Shita and M. Andualem, "Combining ability performance and heterotic grouping of maize (Zea mays L.) inbred lines in testcross formation in Western Amhara, North West Ethiopia," Cogent Food and Agriculture, vol. 6, pp. 1727625, January 2020. https://doi.org/10.1080/23311932.2020.1727625.

[49] M. Amiruzzaman, M. A. Islam, L. Hasan, M. Kadir and M. M. Rohman, "Heterosis and combining ability in a diallel among elite inbred lines of maize (Zea mays L.)," Emir J. Food Agric., vol. 25, no. 2, pp. 132-137, November 2013. DOI: 10.9755/ejfa.v25i2.6084.

[50] J. Derera, B. Tongoona, S. Vivek and M. D. Laing, "Gene action controlling grain yield and secondary traits in southern African maize hybrids under drought and non-drought environments," Euphytica, vol. 162, pp. 411-422, August 2008. https://doi.org/10.1007/s10681007-9582-4.

[51] S. K. Vasal, G. Srinivasan, S. Pandey, F. C. Gonzalez, J. Crossa and D. L. Beek, "Heterosis and combining ability of CIMMYT's quality protein maize germplasm: I. Lowland Tropical," Subtropical. Crop Sci., vol. 33, no. 1, pp. 51-57, January 1993. https://doi.org/10.2135/cropsci1993.0011183X0033000 10006x.

[52] Q. I. M. Mohammad, Md. G. Rasul, A. K. M. Aminul Islam, M. A. Khaleque Mian, Nasrin Akter Ivy and J. U. Ahmed, "Combining ability and heterosis in Maize (Zea mays L.)," American Journal of BioScience, vol. 4, no. 6, pp. 84-90, November 2016. DOI: 10.11648/j.ajbio.20160406.12.

[53] S. P. Singh and H. N. Singh, "Genetic divergence in Okra (Abelmoschus esculentus L. Moerch)," Indian J. Hort., vol. 36, no. 2, pp. 166-170, 1979. ISSN: 0974-0112.

[54] G. Singh, M. Singh and K. R. Dhiman, "Genetic analysis of maize (Zea mays L.) in Sikkim," Indian J. Agri. Sci., vol. 65, no. 4, pp. 293-294, April 1995.

[55] S. Ahmed, S. Begum, M. A. Islam, M. Ratna and M. R. Karim, "Combining ability estimates in maize (Zea mays L.) through line x tester analysis," Bangladesh J. Agril. Res., vol. 42, no. 3, pp. 425-436, September 2017. ISSN: 2408-8293.

[56] X. M. Fan, J. Tan, J. Yang and H. M. Chen, "Combining ability and heterotic grouping of ten temperate, tropical and subtropical quality protein maize," Maydica (Italy), vol. 49, no. 4, pp: 267-272, January 2004. ISSN: 00256153.

[57] K. R. Gowda, U. Kage, H. C. Lohithaswa, B. G. Shekara and D. Shobha, "Combining ability studies in maize (Zea mays L.)," Molecular Plant Breeding, vol. 4, no. 14, pp. 116-127, May 2013. DOI: 10.5376/mpb.2013.04.0014.

[58] D. W. Gissa, H. Zelleke, M. T. Labuschagne, T. Hussien and H. Singh, "Heterosis and combining ability for grain yield and its components in selected maize inbred lines," South African Journal of Plant and Soil, vol. 24, no. 3, pp. 133-137, May 2007. https://doi.org/10.1080/02571862.2007.10634795.

[59] M. A. Abdel-Moneam, A. N. Attia, M. I. El-Emery and E. A. Fayed, "Combining ability and heterosis for some agronomic traits in crosses of maize (Zea mays L.)," Pak. J. Biol. Sci., vol. 12, no. 5, pp. 433-438, March 2009. DOI: $10.3923 /$ pjbs.2009.433.438.

[60] L. M. Moterle, A. L. Braccini, C. A. Scapim, R. J. B. Pinto, L. S. A. Goncalves, A. T. do Amaral Junior and T. R. C. Silva, "Combining ability of tropical maize lines for seed quality and agronomic traits," Genetics and
Molecular Research, Ribeirão Preto. Vol. 10, no. 3, pp. 2268-2278, September 2011. DOI: 10.4238/vol10$3 \mathrm{gmr} 1129$.

[61] P. D. S. Cabral, A. T. do Amaral Junior, H. D. Vieira, J. S. Santos, I. L. J. Freitas and M. G. Pereira, "Genetic effects on seed quality in diallel crosses of popcorn," Ciênc. Agrotec. Lavras, vol. 37, no. 6, pp. 502-511, November 2013. https://doi.org/10.1590/S141370542013000600003.

[62] S. M. Uddin, F. Khatun, S. Ahmed, M. R. Ali and S. A. Begum, "Heterosis and combining ability in field corn (Zea mays L)," Bangladesh J. Bot., vol. 35, no. 2, pp. 109-116, December 2006.

[63] S. M. Uddin, M. M. Amiruzzaman, S. A. Begum, M. A. Hakim and M. R. Ali, "Combining ability heterosis in maize (Zea mays L)," Bangladesh J. Genet Pl. Breed., vol. 21, no. 1, pp. 21-28, June 2008. https://doi.org/10.3329/bjpbg.v21i1.17045.

[64] I. A. Atif, A. A. Awadalla, M. K. Mutasim, E. I. Atif and M. O. Abdellatif, "Combining ability and heterosis for yield and yield components in maize (Zea mays L.)," Australian Journal of Basic and Applied Sciences, vol. 6, no. 10, pp. 36-41, October 2012.

\section{Publish your books with AIJR publisher- \\ * Publish with ISBN and DOI. \\ * Publish Thesis/Dissertation as Monograph. \\ * Publish Book Monograph. \\ * Publish Edited Volume/ Book. \\ * Publish Conference Proceedings \\ * Retain full copyright of your books. Submit your manuscript at books.aijr.org}

Publish your research article in AIJR journals-

* Online Submission and Tracking

* Peer-Reviewed

* Rapid decision

* Immediate Publication after acceptance

- Articles freely available online

* Retain full copyright of your article.

Submit your article at journals.aijr.in 